\title{
Manajemen Modernisasi Pendidikan Islam Berwawasan Lingkungan di Pondok Pesantren Nurul Haramain Narmada Lombok Barat
}

\author{
Zuhaeriah \\ Universitas Nahdatul Wathan Mataram \\ email: zuhaeriah17@gmail.com
}

\begin{abstract}
The current situation is a modern era that cannot be released. Thus it certainly becomes a challenge for the current Islamic education system in developing its institution. Therefore, concrete efforts are needed in contextualizing conditions that are in accordance with the guidance of his time. Thus the management of Islamic education modernization with an environmental perspective of thinking with a pattern that refers to social change. This study is a field research with a qualitative approach in which the researcher tries to describe the research subject. Data collection methods, researchers used the method of observation, interviews / interviews and documentation. As for the analysis, researchers used a qualitative analysis of interactive models. The results of this study Management of Modernization of Islamic Education with Environmental Insight in Nurul Haramain Narmada Islamic Boarding School in West Lombok is through four aspects including: (1) Pesantren based on IT / Multimedia in the Literacy Aspect of Environment, (2) Waste Management with Appropriate Technology Approach, (3) ) Modernization of Education with Environmental Sanitation Aspects (4) Hidden Curriculum Approach for Personal Religious Studies. While the efforts made in implementing the Modernization of Islamic Education Management with Environmental Insights namely; (1) environmental care approach / eco-pesantren program (2) Haramain green management perspective (3) Improving environmental conservation management models (4) Applying volunteer spirit (Philanthropy). This study also concludes that the management of modernization of Islamic education with an environmental perspective on Islamic education is a framework for thinking with the model of locality development or the development of local communities from aspects of local wisdom. Such values are the principle of an approach in creating public awareness to preserve the environment and models in the approach to protecting the environment.

Keywords: Management, Modernization, Islamic Education, Environment

\begin{tabular}{|c|c|c|}
\hline $\begin{array}{c}\text { First Receive: } \\
\text { 25 Mei 2019 }\end{array}$ & $\begin{array}{c}\text { Revised: } \\
\text { 1 Juni 2019 }\end{array}$ \\
\hline $\begin{array}{c}\text { Final Proof Recieved: } \\
\text { 13 Juni 2019 }\end{array}$ & Published: \\
21 Juni 2019 \\
\hline $\begin{array}{c}\text { Zuhaeriah, (2019). Manajemen } \\
\text { di Pondok Pesantren Nurul Haramain Narmada Lombok Barat. Schemata, 8 (1), } \\
\text { 79-106 }\end{array}$ \\
\hline
\end{tabular}
\end{abstract}

\section{PENDAHULUAN}

Dunia Pesantren dikenal dekat dengan nuansa tradisi Islam. Tradisi yang hidup di Pesantren tumbuh dan berkembang di atas dasar cita dan nuansa Islam. Dalam perspektif dan struktur pendidikan berbasis nasional, istilah Pesantren merupakan serangkaian mata rantai yang sangat substantif. Perihal ini tidak hanya karena aspek historis kemunculannya yang relatif lama, tetapi juga kemunculan Pesantren telah secara signifikan berpartisipasi

\section{Copyright () 2019 Schemata Journal}

Available online at http://journal.uinmataram.ac.id/index.php/schemata 
Zuhaeriah, Manajemen Modernisasi Pendidikan Islam Berwawasan Lingkungan...

dalam upaya mencerdaskan kehidupan bermasyarakat dan bangsa. Dari segi sejarah, pola pendidikan pada Pesantren adalah sistem kelembagaan berbasis masyarakat (society basededucation). Ini terbukti dalam kenyataannya bahwa Pesantren telah lama mengakar dan tumbuh di masyarakat dan kemudian dikembangkan oleh masyarakat pula yang terus berevolusi, sehingga kajian-kajian terkait Pesantren sebagai pusat sentral dalam pengembangan masyarakat. ${ }^{102}$

Berbagai pola kebiasaan atau tradisi Pesantren dengan kelebihan dan kekurangannya merupakan bagian dari khazanah budaya bangsa. Ia memiliki andil besar dalam “membumikan" Islam sehingga mudah dicerna dan terhindar dari benturan konfliktual pada masa awal kemunculan dan perkembangannya dengan budaya setempat, melalui cara pewarisan tradisi Islam Abad pertengahan dan akulturasi dengan budaya lokal. Dari sini, pola kesinambungan (continuity) dan perubahan (change) mendapatkan porsi seimbang sebagai bentuk implementasi strategi akomodatif-transformatif. Tidak hanya itu, Pesantren juga diakuai telah berjasa pada upaya pengembangan masyarakat model perspektif swasembada dan swadaya. ${ }^{103}$

Dalam perkembangannya, baik dalam tatanan metodologi maupun keorganisasian Pesantren itu sendiri masih perlu dikembangkan melalui berbagai inovasi-inovasi baru, terlebih lagi perihal modernitas kelembagaan yang identik dengan perkembangan Pesantren era sekarang. Modernisasi merupakan kecenderungan umum dalam berbagai aspek kehidupan baik ekonomi, politik, pendidikan, sosial, dan bahkan nilai-nilai keagamaan. Salah satu aspek yang nampak jelas adalah dalam dunia pendidikan, sebagai aspek yang erat kaitannya dengan modernisasi. Program modernisasi tersebut berawal dari upaya modernisasi pemikiran serta kelembagaan Islam secara menyeluruh. Pola modernisasi sistem pendidikan Islam tidak terpisahkan dengan kebangkitan umat muslimin dimasa modern. ${ }^{104}$

Modernisasi pola pendidikan Pesantren, dipercaya sebagai suatu upaya rekonstruksi keberadaan Pesantren agar tetap resisten dan eksis di tengah tantangan dengan kelembagaan pendidikan modern yang telah lama menawarkan model sistem pendidikan berbasis sekuler melalui manajemen pendidikan sekolah, yang secara historis sengaja didirikan oleh kolonial

\footnotetext{
${ }^{102}$ Eko Setiawan. Modernisasi Pola Sistem Pendidikan Pesantren (Studi Kasus Pondok Pesantren Modern Darul Fikeri Mulyo agung Dau Malang). Pascasarjana Sosiologi Fakultas Pertanian Universitas Brawijaya Malang Telp: 085755597774 email: oke.setia@gmail.com

${ }^{103}$ Abdul Munir Mulkhan, Nalar Spiritual Pendidikan: Solusi Problem Filosofispendidikan Islam, (Yogyakarta: Tiara Wacana, 2002), 180.

104Bashori, Modernisasi Lembaga Pendidikan Pesantren”. Dalam Jurnal Ilmu Sosial Mamangan. Vol. 6. NO, 1 (Januari-Juni 2017): 48.
}

\section{Copyright (C) 2019 Schemata Journal}

Available online at http://journal.uinmataram.ac.id/index.php/schemata 
Zuhaeriah, Manajemen Modernisasi Pendidikan Islam Berwawasan Lingkungan...

Belanda. ${ }^{105}$ Dengan demikian sistem pendidikan perlu dilakukan modifikasi sesuai dengan tuntunan zaman atau esensi dari modernisasi itu sendiri, yakni mampu menyesuaikan dengan konteks dalam menyokong produktivitas intelektual Islam dengan cara meningkatkan standarisasi intelektualitasnya. ${ }^{106}$

Modernisasi pendidikan merupakan salah satu upaya untuk mengadaptasi atau kontekstualisasi sesuai dengan era terbaru atau dimaknai sebagai proses perubahan sikap serta mentalitas sebagai masyarakat agar dapat beradaptasi sesuai dengan tuntutan kekinian. ${ }^{107}$ Bila dilihat korelasi teori di atas berkaitan dalam penelitian ini akan dikaji secara mendalam aspek modernisasi pendidikan Islam di Pondok Pesantren Nurul Haramain dengan menitik beratkan pada aspek pendidikan berbasis lingkungan yang hal ini sejalan dengan kerangka konseptual dari definisi modernisasi itu sendiri sebagai contoh reboisasi yaitu sebuah upaya dalam rangka memperbaharui sumber daya alam yang ada.

Lingkungan merupakan segala hal yang berada disekitar mahluk hidup dan dapat mempengaruhi aktifiktas mahluk hidup. ${ }^{108}$ Lingkungan pendidikan memiliki pengaruh terhadap peserta didik. Contoh dari pengaruh lingkungan adalah ketika peserta didik belajar ditempat yang nyaman dan bersih, maka pembelajarannya akan berpengaruh positif terhadap peserta didik, begitu pula sebaiknya. Menurut Undang-Undang tentang pengelolaan lingkungan hidup No. 23 tahun 1997 dalam siahaan, lingkungan hidup adalah kesatuan ruang dengan semua benda, daya, keadaan, dan mahluk hidup, termasuk manusia dan prilakunya, yang mempengaruhi kelangsungan prikehidupan dan kesejahteraan manusia serta mahluk hidup lain. ${ }^{109}$ Pengelolaan lingkungan hidup merupakan salah satu upaya untuk mengatasi kerusakan lingkungan dan kelangkaan sumber daya alam.

Kebersihan maupun kesehatan di lingkungan madrasah harus diciptakan dalam upaya menciptakan kebersamaan antara dunia pendidikan, guna menumbuhkan sikap sadar akan lingkungan hidup, maka diperlukan adanya upaya penyadaran terhadap pentingnya lingkungan. Apabila proses penyadaran, perubahan sikap dan cara berpikir mengenai lingkungan terjadi, maka dapat diupayakan untuk meningkatkan pengetahuan maupun

\footnotetext{
${ }^{105}$ Mohammad Muchlis Solichin, "Modernisasi Pendidikan Pesantren". Dalam Jurnal Tadris, Jurusan Tarbiyah STAIN Pamekasan.Volume 6, Nomor 1, Juni 2011. 35- 36.

${ }^{106}$ Muhammad Hasan, "Inovasi dan Modernisasi Pendidikan Pondok Pesantren". Dalam jurnal Sosial dan Budaya Keislaman. Vol. 23, No. 2, Desember 2015. 299. hlm. 72

${ }^{107}$ Harapandi Dahri, Modernisasi Pesantren, (Jakarta: Balai Penelitian dan Pengembangan Agama, 2015), hlm. 3

${ }^{108}$ Sirait. T Justia. Memahami Aspek-Aspek Pengelolaan Sumber Daya Manusia. (Jakarta: Gramedia, 2006)
}

${ }^{109}$ Thombang siahaan, Hukum Lingkungan dan Ekologi Pembangunan. (Jakarta Erlangga, 2004) hlm. 110

Copyright (C) 2019 Schemata Journal

Available online at http://journal.uinmataram.ac.id/index.php/schemata 
Zuhaeriah, Manajemen Modernisasi Pendidikan Islam Berwawasan Lingkungan...

pemahaman tentang lingkungan hidup dan meningkatkan keterampilan pengelolaan lingkungan hidup. Penyikapan terhadap hal tersebut, maka perlu diupayakan peningkatan pengetahuan dan pemahaman lingkungan hidup bagi peserta didik dan masyarakat.

Pesantren Nurul Haramain yang merupakan Pesantren sejuta pohon telah mengajarkan kepada santri dan santriwati tentang pentingnya pepohonan di daerah industri saat ini yang merupakan permasalahan ummat secara menyeluruh. Pengetahuan tentang wawasan lingkungan banyak diajarkan di luar pendidikan formal yaitu di sela-sela waktu luang santri. ${ }^{110}$

Dengan demikian yang menjadi catatan penting dalam penelitian ini adalah aspek penerapan pendidikan yang berbasis bidden curriculum (kurikulum tersembunyi). Hidden curriculum Pada dasarnya sebuah proses yang tidak terencana dan memiliki pengaruh besar terhadap gaya belajar bahkan pada aspek kebijakan serta manajemen kebijakan sekolah secara lebih luas dari semua komponen sekolah, dalam hubungan interaksi horizontal dan vertikal. ${ }^{111}$ Dengan demikian aspek penting dari penelitian ini adalah ingin mengkaji bagaimana model yang ada pada Pesantren Nurul Haramain terkait dengan modernisasi/ kontekstualisasi yang dari normative kearah progresif.

Dalam hasil observasi peneliti pada Pondok Pesantren Nurul Haramain tidak ada kurikulum yang secara eksplisit dipelajari dalam ruang kelas terkait dengan wawasan lingkungan, namun ada beberapa sub materi yang dipelajari terkait pentingnya memelihara lingkungan dalam perspektif Islam. Hal ini dapat ditemukan dalam mata pelajaran formal, ${ }^{112}$ yaitu: Qur'an dan Hadis.

Dalam beberapa tinjauan peneliti terkait dengan upaya modernisasi pendidikan Islam berwawasan lingkungan di Nurul Haramain telah meluas baik dalam lingkup nasional maupun internasional. Seperti gerakan 1000 pohon, dalam gerakannya pada dasarnya dari kalangan santri yang merupakan aktor utama dalam melestarikan lingkungan kemudian santri diminta merawat pohon-pohon tersebut sampai benar-benar tumbuh. ${ }^{113}$ Setiap tahun santri/santriwati menanam sekitar 1 juta pohon, mereka juga memiliki kebun pembibitan

${ }^{110}$ Wawanncara bersama Abdul Najib dan observasi awal peneliti

${ }^{111}$ Rohina M Noor, The Hidden Curriculum, (Yogyakarta: Insan Madani, 2012), hal 28

${ }^{112}$ Dalam observasi penulis Nurul Haramain mengklasifikasi menjadi dua jenis kurikulum yaitu kurikulum Depag dan KePondokan. Adapun beberapa Kurikulum Depag seperti; (qur'an hadis, aqidah akhlak, fiqh, SKI, bahasa Arab, bahasa Indonesia, bahasa Inggris, Pkn, Matematika, biologi, fisika, kimia, IPS, penjaskes, bahasa asing, sosiologi dan sejarah kebudayaan. Sedangkan Kurikulum KePondokan (Imla', Muthola'ah, Tamrinullugoh, Muhaddatsah, fara'id, ushul fiqh, nahwu, sharf, reading, tajwid, conversation, mahfudzot, computer, kesenian khot, insya, dan nisaiyyiat.

${ }^{113}$ Heka Hertanto dalam Indonesia satu1co senin 10 Desember 2018 
Zuhaeriah, Manajemen Modernisasi Pendidikan Islam Berwawasan Lingkungan...

seluas satu hektar yang mampu menghasilkan1juta hingga 1, 5 juta bibit pohon per tahun. Gerakan penanaman pohon yang dilakukan oleh pimpinan Pondok Pesantren Nurul Haramain Narmada (TGH Hasanain Juaini, Lc., M.H) yang selama 18 tahun berhasil menyadarkan dan menginspirasi ribuan masyarakat dan Pondok Pesantren untuk bersamasama melakukan gerakan yang sama.

Selain gerakan penanaman pohon guna untuk menghijaukan kembali hutan yang gundul, pimpinan Pondok juga menyelamatkan mata air dan mencegah timbulnya longsor. Kiprahnya yang sangat penting dan strategis adalah melakukan inovasi dalam penanganan sampah, yakni menggunakan tungku pembakaran yang ramah lingkungan dan berbiaya relatif murah. Selain itu ada upaya lain yang dilakukan yaitu dengan jargon "Green Haramain”, penggunaan istilah ini merupakan gerakan labelisasi dalam upaya memperkanalkan Haramain sebagai Pesantren yang memperdulikan lingkungan melalui sistem pendidikan santri/ santriwatinya.

Dari aspek manajerial dan konsistensinya beberapa aktor (TGH. Hasanain Juaini, Lc., M.H) telah mendapatkan penghargaan baik nasional maupun internasional karena pemikirannya terkait dengan pentingnya penghijauan dalam menyelamatkan bumi, berikut penghargaan yang telah di dapatkan: (1) Dinobatkan sebagai tokoh perubahan oleh REPUBLIKA 2015 (2) Penghargaan Roman Magsaysay Award (Nobel Versi Asia) tahun 2011 (3) Ashoka International Foundation Medal for Best Fellow in Religion and Women Empowerment tahun 2003 (4) Piagam pelestarian lingkungan dari pemerintah Lombok Barat tahun 2004 (5) Maarif Award, Ma'arif Institute for Cultural and Humanity tahun 2008. ${ }^{114}$

Melalui kiprahnya Beliau menunjukkan bahwa Pesantren tidak hanya berperan sebagai tempat pembelajaran agama, tetapi juga pembenihan dan penyemaian nilai-nilai transpormatif. Berkat keteladanan, kesabaran, keistiqomahannya, pimpinan Pondok mampu mengubah masyarakat lebih menghargai lingkungannya, dari yang abai menjadi peduli, yang eksploratif menjadi bertanggung jawab, yang berpikiran jangka pendek menjadi visioner. Tentu dari penjelasan di atas mendeskripsikan bawa aktivitas manajerial pada pendidikan Islam tidak hanya dilakukan di dalam kelas, namun juga perlu model pendidikan diluar kelas seperti yang telah dijelaskan sebelumnya bahwa santri merupakan media sebagai sebuah tujuan untuk menciptakan model pendidikan Islam dalam praktik dengan lingkungannya.

\footnotetext{
${ }^{114}$ Wawancara dengan Agus Amrullah Kadir tanggal 20 Januari 2019. Lihat juga https://id.m.wikipedia.org/wiki/hasanain Juaini
} 
Zuhaeriah, Manajemen Modernisasi Pendidikan Islam Berwawasan Lingkungan...

Dalam tulisan ini penulis akan mengedepankan dengan makna substantive darri beberapa teori-teori yang telah dikemukaka oleh parah ahli seperti teori modernisasi ${ }^{115}$, pendidikan Islam ${ }^{116}$, pesantren ${ }^{117}$ dan lingkungan ${ }^{118}$. Dari sini, penulis tertarik untuk mengkaji lebih dalam tentang menejemen modernisasi pendidikan Islam di Pondok Pesantren yang terfokus di Pondok Pesantren Nurul Haramain Narmada. Ada beberapa alasan yang menyebabkan penulis terdorong untuk memilih judul tersebut, diantaranya adalah:

1. Melihat kenyataan bahwa Pesantren Nurul Haramain sebagai salah satu model pendidikan yang khas (indigenous) yaitu pendekatan berbasis nilai-nilai lingkungan, sehingga sangat menarik untuk diteliti secara lebih mendalam.

2. Melihat banyaknya sentimen-sentimen terhadap Pesantren yang normatif bahwa Pesantren adalah suatu lembaga pendidikan Islam yang sifatnya inklusif, fakum, dan tidak kontekstual. Namun Pesantren Nurul Haramain menjawab tantangan tersebut melalui pendekatan lingkungan sebagai basis pendekatan dalam pendidikan Islam.

3. Melihat bahwa Pesantren memiliki kontribusi yang real dalam pembangunan manajemen pendidikan, yaitu pembinaan dan pengembangan santri melalui pentingnya pendidikan dalam perspektif lingkungan.

Berdasarkan latar belakang di atas, penulis mengidentifikasi beberapa masalah yang akan dijadikan bahan penelitian selanjutnnya. Batasan Masalah dalam penelitian ini untuk memaksimalkan penelitian ini perlu dilakukan secara terfokus, maka penulis memandang

115 Kata modern dalam Bahasa Indonesia dikenal dengan kata modern, modernisasi, modernisme seperti “aliran modern dalam Islam" begitu juga "Islam dan modernisasi”. Modernisme pada masyarakat Barat mengandung arti, pikiran, aliran, pergerakan serta usaha untuk merubah faham-faham, adat-istiadat institusiinstitusi lama, dan sebagainya untuk disesuaikan dengan era baru yang disebabkan atas kemajuan ilmu pengetahun dan teknologi modern. Kata modern berasal dari kata modo yang berarti barusan. Bisa juga diartikan sebagai cara berfikir, dan sebuah tindakan yang sesuai dengan eran ata zamannya, sedangkan modernisasi dimaknai sebagai proses perubahan sikap serta mentalitas sebagai masyarakat agar dapat beradaptasi sesuai dengan tuntutan kekinian. Lihat Harapandi Dahri, Modernisasi Pesantren, Jakarta: Balai Penelitian dan Pengembangan Agama, 2015), hlm. 72

116 Pendidikan Islam adalah pada dasarnya adalah teknis bimbingan jasmani maupun rohani yang telah disesuaikan dengan hukum-hukum agama Islam itu sendiri yang bertujuan untuk membentuk kepribadian muslim, yaitu kepribadian yang memiliki nilai-nilai agama Islam. Lihat Nur uhbiyati, Ilmu Pendidika Islam, (Bandung: pustaka setia, 2009), cet. 2 hlm. 5.

117 Pesantren adalah lembaga di mana anak muda dan dewasa belajar lebih mendalam tentang ilmu agama khususnya Islam yang diajarkan secara sistematik, dan umumnya berbahasa Arab dan didukung dengan pembacaan kitab-kitab klasik karangan ulama besar. Lihat Dawan Rahardjo, Pesantren dan Pembaharuan, (Jakarta: LP3S, 2005), Cet. III, hlm.2. atau pendapat lain juga dijelaskan Pondok Pesantren merupakan kelembagaan pendidikan Islam dengan peran sentral kyai sebagai tokoh dan masjid merupakan pusat lembaganya. Pendidikan yang diajarkan di Pondok Pesantren adalah pendidikan agama dan akhlak (mental). Lihat M. Habib Chirzin, "Agama dan Ilmu dalam Pesantren", dalam M. Dawam Rahardjo (ed), Pesantren dan Pembaharuan, (Jakarta: LP3ES, 2008), Cet. VIII, hlm. 82.

\section{Copyright () 2019 Schemata Journal}

Available online at http://journal.uinmataram.ac.id/index.php/schemata 
Zuhaeriah, Manajemen Modernisasi Pendidikan Islam Berwawasan Lingkungan...

banyak permasalahan yang cukup kompleks maka penelitian yang diangkat perlu dibatasi, oleh sebab itu penulis membatasi hanya dengan hal yang berkaitan pada upaya "manajemen modernisasi yang telah dilakukan pada aspek Pendidikan Islam berwawasan lingkungan di Pondok Pesantren Nurul Haramain". Hal ini dipilih agar arah penelitian tidak terlalu melebar sehingga berdampak bias. Dengan mengangkat Rumusan Masalah sebagai berikut: (1) Apa yang melatar belakangi pimpinan Pondok dalam menerapkan memanajemen modernisasi Pendidikan Islam berwawasan lingkungan di Pondok Pesantren Nurul Haramain Narmada Lombok Barat ?’ (2) Upaya-upaya apa saja yang dilakukan dalam menerapkan manajemen modernisasi Pendidikan Islam berwawasan lingkungan di Pondok Pesantren Nurul Haramain Narmada Lombok Barat?

\section{METODE PENELITIAN}

Pendekatan penelitian ini menggunakan metode kualitatif deskriptif, karena permasalahan belum jelas, holistik, kompleks dan dinamis sehingga tidak mungkin data pada situasi sosial tersebut dijaring dengan metode penelitian kuantitatif. Penelitian kualitatif adalah sebagai prosedur yang menghasilkan data deskriptif berupa data lisan dari orang-orang dan pelaku yang dapat diamati. ${ }^{11}$ Dalam penelitian ini sumber data penelitian dipilih secara purposive adalah teknik pengambilan sumber data dengan pertimbangan tertentu. Pertimbangan tertentu, misalnya orang tersebut dianggap lebih tahu tentang apa yang kita harapkan atau mungkin dia sebagai penguasa, sehingga akan memudahkan peneliti menjelajahi obyek/situasi sosial yang akan diteliti.

Tekhnik pengumpulan data yang di gunakan adalah observasi, wawancara, dan dokumentasi. Untuk tekhnik analisis data dilakukan sebelum memasuki lapangan, selama di lapangan dan setelah selesai di lapangan. Analisis selama di lapangan yang digunakan peneliti adalah model Miles and Huberman. Analisis data dilakukan pada saat pengumpulan data berlangsung dan setelah selesai pengumpulan data dalam periode tertentu. Miles and Huberman mengemukakan bahwa aktifitas dalam analisis data kualitatif di lakukan secara interaktif dan berlangsung secara terus menerus sampai tuntas sehingga datanya jenuh. ${ }^{20}$ Dalam uji keabsahan data dalam penelitian kualitatif, data dinyatakan valid apabila tidak ada perbedaan antara yang dilaporkan peneliti dengan apa yang sesungguhnya terjadi. Adapun

\footnotetext{
${ }^{119}$ Lexy J. Moloeng, Metodologi Penelitian Kualitatif, (Bandung:PT Remaja Rosdakarya,2010),h.3.”

120 Sugiyono, Metode Kuantitatif Kualitatif dan ReDD, (Bandung: Alfa Beta. CV, 2 009), h. 246.
} 
Zuhaeriah, Manajemen Modernisasi Pendidikan Islam Berwawasan Lingkungan...

yang akan digunakan peneliti dalam menguji keabsahan data yaitu uji kredibilitas, kecakupan refrensi, dan keikutsertaan peneliti.

\section{HASIL DAN PEMBAHASAN}

1. Latar Belakang Pimpinan Pondok Dalam Menerapkan Manajemen Modernisasi Pendidikan Islam Berwawasan Lingkungan Di Pondok Pesantren Nurul Haramain Narmada Lombok Barat

Berangkat dari kegelisahan dalam kehidupan sehari-hari serta dengan kondisi alam yang banyaknya lahan-lahan yang kurang produktif. Menurut investasi ada 33 juta lahan krisis, maka untuk mengembalikannya membutuhkan 33 miliar pohon. Bila dalam setahun menanam 1 miliar pohon maka membutuhkan 55 tahun untuk mengembalikannya. Setiap orang menghabiskan 1270 batang pohon untuk segala keperluan manusia seperti; jadi buku, rumah, pakaian dan lain sebagainya. ${ }^{121}$

Dengan latar permasalahan di atas merupakan fakta historis yang menjadikan TGH. Hasanain berfikir keras terkait dengan hal dalam menyelesaikan masalah-masalah lingkungan yang ada saat ini. Dengan demikian setiap tahun TGH. Hasanain dan para santri menanam pohon sekiatr 1 juta, hingga 1,5 juta bibit pohon dan ada juga yang dibagikan kepada masyarakat secara cuma-cuma/ gratis. Gerakan penanaman pohon yang dilakukan selama 18 tahun berhasil menyadarkan dan menginspirasi ribuan masyarakat dan Pondok Pesantren untuk bersama-sama melakukan gerakan yang sama.

Gerakan ini sejak dimassifkan dari tahun 2010 hingga saat ini telah berdampak besar terhadap timbulnya kesadaran masyarakat dalam menjaga lingkungan, hal ini dapat dilihat dari tingginya jumlah permintaan pembibitan pohon yang disediakan oleh Nurul Haramain tiap tahunnya. Artinya dalam kurun waktu satu dekade telah mengalami perubahan yang signfikan.

Pondok Pesantren Nurul Haramaian merupakan salah satu lembaga pendidikan yang cukup komprehensif dalam menjalankan aktivitas pendidikannya dengan berbagai pendekatan-pendekatan tertentu salah satunya adalah melalui pendekatan pengolahan lingkungan dan penghijauannya. Tentu dalam proses pelaksanaan visi-misi tersebut dibantu oleh berbagai pihak salah satunya adalah dengan melibatkan santri dan santriwati

121 Wawancara bersama TGH. Hasanain Djuaini pada tanggal 23 Mei 2017. Lihat juga channel youtube TGH. Hasanain sebagai tokoh perubahan Kompas TV.

Copyright (C) 2019 Schemata Journal

Available online at http://journal.uinmataram.ac.id/index.php/schemata 
Zuhaeriah, Manajemen Modernisasi Pendidikan Islam Berwawasan Lingkungan...

dalam aktivitas mulai dari pembibitan hingga penanaman serta pengelolaan limbahlimbah cair dan padat yang ada serta didukung dengan fasilitas-fasilitas modern saat ini.

Pesantren Nurul Haramain dari hasil observasi dan interview peneliti melihat bahwa Pesantren menerapkan dua model belajar yaitu; dengan berbasis modern dan klasik atau tradisi lama. ${ }^{122}$ Dengan demikian dalam tulisan ini peneliti menekankan pada aspek pemanfaatan sumber daya modern dalam menunjang pembelajaran berwawasan lingkungan.

Modernisasi pendidikan Islam Manajemen Berwawasan Lingkungan merupakan kerangka konseptual yang memadukan antara pentingnya pendidikan dengan lingkungan yang didukung dengan pendekatan dan ciri dari aspek modernitas. Perspektif ini menawarkan tentang sebuah model berfikir antara perpaduan dua pendekatan yaitu modern dan lingkungan serta didukung atas eksistensi nilai-nilai keagamaan. Kedua model ini akan melahirkan beberapa gagasan yang produktif dan membutuhkan pendalaman tindak lanjut.

Gambar 3. Ilusrasi Paradigma Integrasi-Interkoneksi Pendidikan Islam berbasis Lingkungan Modern

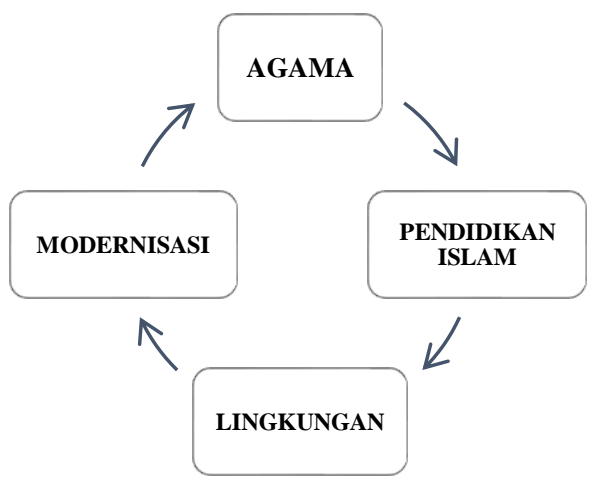

Deskripsi gambar di atas memiliki keterhubungan yang erat antara agama Islam, lingkungan, pendidikan dan dunia modern. Karena kelima hal ini tidak bisa dipisahlan satu sama lain dan saling melengkapi. Dengan demikian dalam tesis ini peneliti akan mengungkankan berbagai pola-pola yang telah diterapkan dalam beberapa lembaga sistem pendidikan Islam dan khusus di Pondok Pesantren Nurul Hramain Narmada. Tentunya bila dikaji secara mendalam teori-teori modernisasi menekakan pada

${ }^{122}$ Pembelajaran modern dimaksud di sini adalah penggunaan alat-alat mutakhir saat ini. Sedangkan pembelajaran klasik santri juga diajarkan memahami kitab-kitab terdahulu seperti bulugul maram, riyadussalihin, matan al-jurumiyyah, ushul fiqh dan kitab-kitab hadis dan tafsir lainnya. 
Zuhaeriah, Manajemen Modernisasi Pendidikan Islam Berwawasan Lingkungan...

pentingnya aspek penyesuaian waktu dan masa tanpa dibatasi waktu dan tempat. Artinya bahwa penyesuaian dengan lingkungan merupakan prasayarat dalam menerapkan ide-ide modernitas. Singkatnya modernisasi adalah sebuah cara berfikir yang mengedepankan asas adaptif masa kini. ${ }^{123}$

Dalam penelitian ini peneliti melihat bahwa Pesantren Nurul Haramain telah mejewantahkan dan mengaplikasikan modernisasi pendidikan Islam dengan pendekatan lingkungan dengan pemanfaatan media dan pemanfaatan IT dan multimedia sebagai media bagi santri dan santriwati dalam mengakses tentang pentingnya lingkungan hidup dan bagaimana tata cara pelestariannya.

Fakta lain peneliti menemukan bahwa basis penerapan pendidikan berwawasan lingkungan adalah dari segi pegajaran berbasis aplikatif problem base learning atau pembelajaran berbasis penyelesaian masalah. Hemat peneliti model seperti ini merupakan sebuah model yang yang kontekstual/modernitas. Dan pondok pesantren Nurul Haramain telah mengekplorasikan dalam bentuk bahwa pendidikan lingkungan merupakan bagian dari salah satu petingnya dalam menyelesaikan masalah baik sosial maupun kesehatan. Untuk lebih jelasnya berikut dijelaskan secara spesifik pada sub tema di bawah ini terkait dengan hal-hal penerapan modernisasi pendidikan Islam di Nurul Haramain diantaranya :

\section{Pesantren berbasis IT/Multimedia Pada Aspek Literasi Kelingkunganan}

Teknologi merupakan bagian integral dalam setiap budaya makin maju suatu budaya, makin banyak dan makin canggih teknologi yang digunakan didalam dunia pendidikan, peran dan posisi teknologi pendidikan juga merupakan bagian integral dari pendidikan. Namun pada kenyataannya masih banyak yang belum mengakui bahkan mengasah keberadaan teknologi pendidikan untuk membantu mengatasi masalah pendidikan pada umumnya dan pembelajaran pada khususnya. Untuk itu para teknologi pendidikan baik praktisi maupun akademisi harus berpikir dan bertindak proaktif untuk menjawab tantangan tersebut, dengan membuktikan dan mengembangkan teknologi pendidikan sehingga manfaatnya luas, apalagi dalam menghadapi era global. Dalam tesis ini akan dibahas mengenai bagaimana konsep teknologi pendidikan dan prosfek serta tantangan apa yang akan di hadapi di era global ini.

${ }^{123}$ Lebih jelasnya penjelasan modernisasi dapat dilihat pada sub bab kerangka teoritik 
Zuhaeriah, Manajemen Modernisasi Pendidikan Islam Berwawasan Lingkungan...

Teknologi pendidikan merupakan penerapan praktis pengetahuan untuk mengerjakan sesuatu yang kita inginkan dalam dunia pendidikan. Dalam perkembangannya, teknologi pendidikan mengalami tantangan di era globalisasi. Oleh karena itu teknologi pendidikan harus mempunyai prosfek di era globalisasi ini. Di era globalisasi ini, teknologi pendidikan digunakan atau dikaitkan dengan proses pembelajaran untuk mencapai Tujuan Instruksional Umum (TIU) dan Tujuan Intruksional Khusus (TIK). Sehingga penggunaan teknologi pendidikan dalam dunia sekolah dapat mencapai hasil yang optimal.

Pesantren Nurul Haramain merupakan salah satu Pondok Pesantren yang menerapkan system pendidikannya melalui pendekatan penggunaan teknologi termasuk pemanfaatan IT yang berkembang saat ini. Penggunaan IT ini merupakan bagian dari terobosan dalam upaya mengkontektualisasikan tantangan-tantangan global yang membutuhkan indigenisasi agar sesuai dengan kebutuhan saat ini.

Pondok Pesantren Nurul Haramain saat ini memiliki digital library (perpustakaan digital) yang memiliki koleksian hingga ribuan buku, tentu dengan sumber daya yang ada para stake holder mengarahkan kepada santri/santriwati untuk memanfaatkan potensi yang ada termasuk dalam hal ini terkait dengan aspek lingkungan hidup. Pemangku kepentingan menginstruksikan kepada santri dan santriwati untuk mempelajari lingkungan hidup serta bagaimana upaya menjaganya karena hal ini merupakan bagian dari pada upaya pemanfaatan sumber daya modern untuk kebutuhan saat ini maupun masa mendatang.

Tantangan global saat ini tentu perlu dijawab dengan dua pendekatan yaitu pendekatan tekstual dan kontekstual. Nurul Haramain dengan pendidikan literasi merupakan jawaban dari pentingnya memahami tekstual, sedangkan IT dan penggunaan multimedia merupakan pentingnya dari aspek kontekstual. Dengan pemanfaatan kedua pendekatan tersebut maka sistem pendidikan mampu menjawab tantangan global serta dengan mudah dapat beradaptasi dengan situasi saat ini. Literasi yang diajarkan pada pendidikan santri dan santriwati adalah memahami ayat-ayat maupun hadis serta pendekatan agama lainnya dengan tujuan memahami serta bagaimana memperlakukan alam semesta (makro kosmos).

Perlu digaris bawahi dalam tulisan ini memotret model inovasi dan modernisasi dalam konteks pendidikan Islam di Pesantren. Kajian inovasi dan modernisasi Pesantren menarik karena mengandung beberapa makna penting, pertama, kajian inovasi dan

\section{Copyright $\odot 2019$ Schemata Journal}

Available online at $\mathrm{http}: / /$ journal.uinmataram.ac.id/index.php/schemata 
Zuhaeriah, Manajemen Modernisasi Pendidikan Islam Berwawasan Lingkungan...

modernisasi Pesantren merupakan kajian yang relevan dalam konteks keindonesiaan yang sedang melakukan proses pembangunan dan modernisasi; kedua, Pesantren merupakan sub kultur pendidikan Islam Indonesia sehingga dalam menghadapi inovasi dan modernisasi akan memberikan warna yang unik; ketiga, pendidikan Pesantren merupakan prototype model pendidikan yang ideal bagi bangsa Indonesia. Tulisan ini menyimpulkan bahwa terma inovasi dan modernisasi terkait dengan perubahan sosial. Dalam konteks Pesantren saat ini, setidaknya ada tiga aspek dalam modernisasi, inovasi, dan pembaruan Pesantren, yaitu pada aspek metode, isi materi, dan manajemen pengelolaanya.

Dari uraian di atas dapat berimplikasi: Pertama, inovasi dan modernisasi terkait dengan perubahan sosial. Perbedaannya hanya pada penekanan ciri dari perubahan itu. Inovasi menekankan pada ciri adanya sesuatu yang diamati sebagai sesuatu yang baru bagi individu atau masyarakat, sedangkan modernisasi menekankan pada adanya proses perubahan dari tradisional ke modern, atau dari yang belum maju ke yang sudah maju. Jadi penerimaan suatu inovasi adalah tanda adanya modernisasi. Kedua, ada tiga aspek dalam modernisasi, inovasi, dan pembaruan Pesantren, yaitu metode,isi materi, dan manajemen. ${ }^{124}$

Nilai lebih dari pemanfaatan IT berbasis library digital adalah dapat mengefesiensi akan kebutuhan-kebutuhan yang terbatas terutama dalam menghadirkan buku dalam bentuk hard copy karena dalam bentuk ini membutuhkan biaya yang cukup tinggi. Serta membatasi penggunaan kertas yang berlebihan.

\section{Manajemen Sampah dengan Pendekatan Teknologi Tepat Guna}

Salah satu upaya dalam pemecahan masalah yang dialami saat ini adalah berbagai problema limbah padat dan cair. Tentu problematika semacam ini memerlukan upaya penanganannya salah satunya adalah dengan konsep teknologi tepat guna. ${ }^{125}$

\footnotetext{
${ }^{124}$ Muhammad Hasan Inovasi Dan Modernisasi Pendidikan Pondok Pesantren Karsa: Jurnal Sosial dan Budaya Keislaman Vol. 23 No. 2, Desember 2015: 295-305

${ }^{125}$ Sebelum membahas lebih jauh tentang pengalaman dalam penerapan TTG, ada baiknya kita menyamakan persepsi terlebih dahulu terkait dengan filosofi dan tujuan dari teknologi tepat guna itu sendiri. Dari berbagai pengertian yang ada - baik yang telah diadopsi oleh pemerintah melalui Inpres No 3 tahun 2001[6], Permendagri No 20/2010[7], maupun yang tertuang dalam visi misi B2PTTG LIPI - setidaknya dapat kita rangkum pemahaman TTG ini ke dalam 4 pilar utama yang tidak dapat dipisahkan satu sama lain, yaitu (1) layak secara teknis (2) menguntungkan secara ekonomi (3) diterima secara sosial-budaya dan (4) ramah terhadap lingkungan. Sasaran implementasi TTG menurut dua peraturan diatas (Inpres 3/2001 dan Permendagri 20/2010) secara umum sama, yaitu golongan miskin (masyarakat penganggur, putus sekolah, dan keluarga miskin), golongan wirausaha (masyarakat yang memiliki usaha mikro, kecil dan menengah) kawasan (pedesaaan dan perkotaan) serta institusi yang membutuhkan. Dengan pemahaman tersebut, implementasi TTG bukan saja mampu mendorong peningkatan taraf hidup masyarakat miskin, tetapi juga dapat menjadi strategi jangka panjang untuk meraih kesejahteraan secara berkelanjutan.
}

Copyright $(92019$ Schemata Journal

Available online at http://journal.uinmataram.ac.id/index.php/schemata 
Zuhaeriah, Manajemen Modernisasi Pendidikan Islam Berwawasan Lingkungan...

Pondok Pesantren Nurul Haramain atau hemat penulis Pondok modern Haramain adalah Pondok yang memamadang bahwa penemuan-penemuan serta belajar memahami korelasi antara alam dengan permasalahannya salah satunya adalah tempat pengumpulan sampah sekaligus alat untuk pengolahan sampah. Tentu model seperti ini adalah salah satu model yang sangat eco modern dalam memperilakukan lingkungan sekitar serta penggunaan alat-alat sederhana dalam pengelolaan sampah dan pembuatan pembibitan pohon. Catatan penting adalah umumnya praktik pendidikan seperti ini lazimnya dilakukan oleh santri/santriwati sebagaimana telah diceritakan dalam bab sebelumnya.

Dengan demikian, pendektan teknologi tepat guna merupakan cara berfikir praktis, simpel, modern, dan adaptif. Model yang demikian merupakan prospek yang merupakan bagian integral dari proses pembelajaran pendidikan lingkungan. Berikut beberapa hal yang terkait dengan pentingnya penggunan tekno modern dalam upaya pemanfaatan potensi pendidikan kekinian:

1. TTG mampu menciptakan Know Ledge Society yaitu masyarakat yang berkeyakinan bahwa eksistensi TTG jauh lebih penting dan mampu memanfaatkannya dengan sumber alam, materi yang melimpah, dan modal yang ada.

2. TTG merupakan sebuah kebijakan dalam menyelesaikan problematika di dalam kehidupan bermasyarakat.

3. TTG mampu menembus jarak ruang dan waktu dalam setiap pola kehidupan

4. TTG memberikan pengetahuan baru tentang sains dalam mempelajari kehidupan ini.

5. Teknologi tepat guna mempermudah untuk memperoleh kebutuhan dasar yang dapat membantu kita dalam memecahkan masalah

6. TTG harus mampu dan selalu mengupayakan adanya inovasi- inovasi baru guna menjaga keutuhan teknologi tepat guna (TTG).

7. TTG harus mampu meningkatkan pembangunan berwawasan lingkungan yang juga bisa dinikmati dan dilakukan oleh masyarakat menengah ke bawah.

Pada hakikatnya penggunaan akan teknologi yang sesuai dengan kebutuhan untuk menjawab berbagai permasalah yang ada merupakan core values dari asas nilai-nilai manajemen pendidikan Islam modern itu sendiri. Sebagai contoh nya adalah terkait dengan Kompester samapah organik yang bisa dimanfaatkan sebagai pupuk kompos untuk tanaman. Ternyata, alat untuk mengubah sampah organik menjadi kompos dan digunakan untuk bahan untuk batu bata/batako yang merupakan salah satu teknologi

\section{Copyright $@ 2019$ Schemata Journal}

Available online at http://journal.uinmataram.ac.id/index.php/schemata 
Zuhaeriah, Manajemen Modernisasi Pendidikan Islam Berwawasan Lingkungan...

tepat guna yang biasa dibuat di pesantren dan diajarkan kepada santri dan santriwati secara komprehensif.

Dari contoh di atas alat Teknologi Tepat Guna ${ }^{126}$ Sederhana tidak terlepas dari perkembangan zaman bahwa setiap manusia akan terus berinovasi dalam menciptakan suatu teknologi, dimana teknologi tersebut dibuat untuk memudahkan manusia dalam melakukan suatu pekerjaan.

\section{Modernisasi Pendidikan Dengan Aspek Sanitasi Lingkungan}

Sanitasi lingkungan adalah Status kesehatan suatu lingkungan yang mencakup perumahan, pembuangan kotoran, penyediaan air bersih dan sebaginya. Secara keseluruhan sanitasi lingkungan tidak dapat dipisahkan dari kehidupan sehari-hari.

Bila dilihat pernyataan di atas baik dalam tinjauan teoritis maupun praktis sanitasi lingkungan merupakan sebuah keharusan dalam upaya menjaga lingkungan. Perilaku seperti ini merupakan tuntunan wajib bagi setiap individu. Dalam perspektif manajmen Pesantren Nurul Haramain tentu dalam aplikasi telah diajarkan kepada santri dari segi teori dan praktik. Dengan demikian pola perubahan perilaku seperti ini merupakan perilaku positif baik jangka pendek terlebih dalam jangka panjang.

Nilai inti dari aspek ini adalah mendeskripsikan bahwa pola modernisasi lingkungan dengan menjadikan proses pendidikan sebagai core values tentu akan berdampak terhadap makna substansi dari pola manajem pendidikan itu sendiri. Sudah menjadi sebuah keharusan bahwa meninjau serta memahami makna-makna yang terkandung dalam beberapa pernyataan tentang konsepsi sanitasi lingkungan.

Hemat peneliti Pondok Pesantren Nurul Haramain merupakan salah satu role model dari sebuah lembaga pendidikan yang sangat memperhatikan tentang pentingnya sanitasi lingkungan. Ada tiga konsep yang perlu diketahui dalam lingkungan yaitu, fisik, biologis dan lingkungan sosial.

WHO menjelaskan bahwa sanitasi lingkungan adalah suatu keseimbangan ekologi yang harus ada antara manusia dan lingkungan agar dapat menjamin keadaan sehat dari manusia, keadaan sehat mencakup manusia seutunya dan tidak hanya sehat secara fisik namun juga mental dan hubungan sosial di dalam lingkungan. ${ }^{127}$

\footnotetext{
${ }^{126}$ Teknologi tepat guna mulai tenar ketika terjadi berbagai gerakan perlindungan lingkungan tahun 1970 dan krisis minyak pada tahun 1973. Masyarakat mulai memikirkan teknologi yang lebih ramah lingkungan dan ramah sosial untuk digunakan (setidaknya lebih ramah lingkungan dibanding teknologi pabrik saat itu). Alat alat teknologi tersebut akan digunakan untuk meringankan pekerjaan manusia namun tetap menghemat sumber daya yang ada, mudah dibuat dan mudah dirawat oleh manusia.
}

${ }^{127}$ WHO, Linking Program Evaluation to User Needs, The Politiccs of Program Evolution, Sage, USA. 2002

\section{Copyright (C) 2019 Schemata Journal}

Available online at http://journal.uinmataram.ac.id/index.php/schemata 
Zuhaeriah, Manajemen Modernisasi Pendidikan Islam Berwawasan Lingkungan...

Tentu penekanan penting adalah lingkungan selain untuk menjaga keseimbangan alam namun juga dapat berguna bagi kesehatan fisik seseorang. Itu artinya manajemen dan pendidikan yang baik adalah mampu mengeksplorasi akan nilai-nilai yang holistic yaitu nilai yang mencakup bagi keseluruhan akan kebutuhan manusia.

\section{Pendekatan Hidden Curriculum Studi Religious Personal}

Yang akan ditekan dalam sub ini adalah bagaimana pengajaran tentang perilaku dalam memelihara lingkungan yang pada umumnya santri/santriwati diajarkan atau diselitkan materi-materi tentang lingkungan dalam studi-studi keagamaan melalui pembelajaran ayat-ayat dan hadis-hadis tentang lingkungan. Di muka pada bab sebelumnya telah dijelaskan bahwa menjaga lingkungan serta menjaganya bukanlah sebuah perilaku untuk manusia belaka, namun ini merupakan tuntunan sang pencipta yang dalam beberapa ayat lingkungan dapat ditemukan. ${ }^{128}$

Dengan menumbuhkan kesadaran personal maka akan berimplikasi kepada upaya perubahan perilaku sosial dan lingkungan. Tentu dalam melakukan perubahan membutuhkan waktu yang cukup lama serta analisa yang panjang. Esensinya dalam membangun sebuah konsep lingkungan membutuhkan starting point yang memumpuni.

Dengan demikian pendekatan ini agama sebagai sumber nilai dapat merubah alam menjadi suatu sumber kehidupan yang positif (manfaat) maupun negatif (madarat). Sebagian ahli pikir mencoba menggunakan Islam sebagai sistem nilai dan norma untuk memecahkan masalah kehidupan seluruh makhluk di bumi ini sebagai ungkapan rasa tanggung jawab. Lingkungan hidup merupakan satu kesatuan sistem dan memiliki hubungan yang sanagat banyak dengan penghuni, banyak interaksi dan korelasinya. Lingkungan hidup dalam pandangan Islam tidak terlepas dari proses penciptaan Allah yang tidak secara kebetulan. Kejadian alam semesta yang sistematik mengarahkan manusia agar mampu menghayati wujud, keesaan dan kebesaran Allah. Mengingat karena semua kerusakan atau pencemaran lingkungan disebabkan karena ulah manusia, maka amar ma'ruf nahi mungkar adalah cara terbaik untuk menanggulangi hal tersebut dengan tinjauan secara teologis dan fenomenologis.

Jadi antara agama, lingkungan hidup, pandangan hidup merupakan kerangka berfikir terintegrasi. Artinya bahwa dalam memadukan antara agama dan lingkungan hal

${ }^{128}$ (Q.S`al-A'raf [7]:56).

\section{Copyright $\odot 2019$ Schemata Journal}

Available online at $\mathrm{http}: / /$ journal.uinmataram.ac.id/index.php/schemata 
Zuhaeriah, Manajemen Modernisasi Pendidikan Islam Berwawasan Lingkungan...

ini tak dapat terpisahkan atau dikotomi. Tantangan yang demikian merupakan hal yang menjadi tanggung jawab setiap pemangku pendidikan dalam dunia Pesantren saat ini.

Namun,seiring dengan perkembangan zaman, lebih-lebih di era globalisasi seperti sekarang ini, Pesantren kini menghadapi masalah-masalah (akibat dampak globalisasi) yang tidak kunjung selesai bahkan hingga membenang kusut. Akibatnya, Pesantren kini dipandang oleh banyak kalangan (baik dari pengelola pendidikan Islam itu sendiri maupun masyarakat luas) sebagai pendidikan kelas dua (second class).

Karena itu, agar Pesantren mampu terus memainkan perannya dengan baik, yakni menjadi produsen yang menghasilkan manusia-manusia yang berilmu, berteknologi, berketerampilan tinggi, dan sekaligus beriman dan beramal saleh, ia harus dimodernisasi secara serius sesuai dengan kerangka modernitas. Sebab, mempertahankan pemikiran kelembagaan Islam “tradisional” hanya akan memperpanjang nestapa ketidak berdayaan kaum muslim dalam berhadapan dengan kemajuan dunia modern. ${ }^{129}$

Pesantren telah menorehkan sumbangsih yang besar dalam proses mencerdaskan generasi bangsa. Namun, dalam konteks kekinian Pesantren tidak bisa mengelak dari pengaruh modernisasi, terutama perkembangan zaman yang diiringi oleh kemajuan ilmu pengetahuan dan teknologi. Pesantren dihadapkan pada tantangan-tantangan yang ditimbulkan oleh kehidupan modern. Sedangkan kemampuan Pesantren dalam menjawab tantangan tersebut dapat dijadikan parameter seberapa jauh dia dapat mengikuti arus modernisasi. Masalah yang dihapai Pesantren terhadap arus modernisasi dapat diklasifikasikan sebagai berikut; Pertama, dari segi kepemimpinan Pesantren secara kukuh masih terpola dengan kepemimpinan yang sentralistik dan hierarkis yang berpusat pada satu orang Kiai. Kedua, kelemahan di bidang metodologi, Pesantren mempunyai tradisi yang kuat di bidang transmisi keilmuan Modernisasi Pendidikan Pesantren Perspektif klasik.

Namun karena kurang adanya improvisasi metodologi, proses transmisi itu hanya melahirkan penumpukan keilmuan. Ketiga, masalah kurikulum Pesantren yang sudah usang. Hal tersebut umunya Pesantren sebagai lembaga pendidikan Islam, materi pembelajarannya lebih mengutamakan pelajaran agama Islam yang bersumber dari kitabkitab klasik, seperti tauhid, hadis, tafsir, fiqih dan sejenisnya. Kurikulum didasarkan pada tingkat kemudahan dan kompleksitas kitab-kitab yang dipelajari, mulai dari tingkat awal,

\footnotetext{
${ }^{129}$ Muhammad Heriyudanta Modernisasi Pendidikan Pesantren Perspektif Azyumardi Azra Mudarrisa, Jurnal Kajian Pendidikan Islam, Vol. 8, No. 1, Juni 2016: 145-172 146
} 
Zuhaeriah, Manajemen Modernisasi Pendidikan Islam Berwawasan Lingkungan...

menengah dan lanjut. Keempat, terjadinya disorientasi, yakni Pesantren kehilangan kemampuan mendefinisikan dan memosisikan dirinya di tengah realitas sosial yang sekarang ini mengalami perubahan yang demikian cepat.

Dari keempat persoalan tersebut Azra ${ }^{130}$ menawarkan solusi. Untuk permasalahan pertama dapat diselesaikan dengan pembaruan sistem manajemen dan kepemimpinan. Kepemimpinan yang semula besifat sentralistik dan hierarkis yang berpusat pada satu orang Kiai, harus ditransformasikan menjadi manajemen dan kepemimpinan kolektif. Dengan perubahan pola kepemimpinan semacam ini, Pesantren sangat berpotensi untuk tidak merosot bahkan lenyap sepeninggal figur tokoh sentral seorang Kiai. Masalah kedua dapat diatasi dengan kontekstualisasi dan improvisasi metode pembelajaran atau bahkan membangun sebuah paradigma baru yang berorientasi pada paradigma emansipatoris. Masalah ketiga dapat diatasi dengan cara tidak jauh berbeda dengan masalah kedua, yakni kontekstualisasi kurikulum dengan zaman yang tengah berlangsung. Adapun masalah keempat dapat diatasi dengan mengimplementasikan kaidah hukum "Al-Mukhafadzatu 'ala al-qadim al-ashalih wa al-akhzu bi al-jadid al-ashlah, artinya melestarikan nilai Islam yang baik dan mengambil nilai-nilai baru yang sesuai dengan konteks zaman agar tercapai akurasi metodologis dalam mencerahkan peradaban bangsa.

2. Upaya-Upaya Yang Dilakukan Dalam Menerapkan Memanajemen Modernisasi Pendidikan Islam Berwawasan Lingkungan Di Pondok Pesantren Nurul Haramain Narmada Lombok Barat

Bebicara tentang upaya maka hal yang banyak ditijau adalah dari dua aspek yaitu aspek sejarah dan aspek future. Maksud dari aspek sejarah adalah ingin melihat upayaupaya apa saja yang telah dilakukan dalam upaya memode rnisasi proses pendidikan di Pesantren Nurul Haramain terutama dalam melibatkan santri secara langsung dalam pelestarian lingkungan. Sedangkan aspek future mengenai langkah konkrit kedepannya apa saja yang akan dilakukan guna menjaga sustabality dari wacana tersebut. Secara umum beberapa upaya yang telah dilakukan dalam mengembangkan pesantren berbasis lingkungan sejak tahun 2010 hingga saat ini diantaranya:

${ }^{130}$ Muhammad Heriyudanta "Modernisasi Pendidikan Pesantren Perspektif Azyumardi Azra" Mudarrisa, Jurnal Kajian Pendidikan Islam, Vol. 8, No. 1, Juni 2016: 145-172

Copyright (C) 2019 Schemata Journal

Available online at http://journal.uinmataram.ac.id/index.php/schemata 
Zuhaeriah, Manajemen Modernisasi Pendidikan Islam Berwawasan Lingkungan...

\section{Pendekatan peduli lingkungan/ program eco-Pesantren,}

Eco-Pesantren yang menurut Siswanto merupakan model pendidikan yang dapat mentransformasikan nilai-nilai moral keagamaan dalam berinteraksi dengan lingkungan, dimana proses pendidikan berorentasi pada pembentukan manusia secara utuh, baik lahiriah maupun batiniah dalam totalitasnya sebagai khalifah; pengatur dan pemeliharaan alam dan lingkungan. ${ }^{131}$

Dengan demikian, pendidikan melalui model eco-Pesantren diharapkan santri memiliki bekal ilmu yang seimbang antara ilmu duniawi (berorientasi pada kehidupan di dunia) dengan ilmu ukhrowi (berorientasi pada kehidupan di akhirat), sehingga dapat menyeimbangkan antara ibadah mabdhah (hubungan dengan Tuhan) dengan ibadah ghairu mabdhah (hubungan dengan makhluk: manusia dan alam) serta dapat menerapkan konsep Islam yang utuh, yaitu rahmatan lil'alamin (kesejahteraan bagi seluruh alam). Untuk itu, santri dan santriwati perlu dibekali dengan ilmu-ilmu kontekstual terkait lingkungan hidup dan konservasi melalui program pendidikan konservasi dengan model ecoPesantren.

Menciptakan kesadaran individu kemudian dilaksanakan secara kolektif merupakan bagian dari tuntunan dan tanggung jawab bersama. Dengan demikian perspektif seperti ini merupakan langkah dasar dalam membina serta menjaga lingkungan dengan memanfaatkan pengetahuan yang bersifat modern serta mampu menjawab tantangan-tantangan yang semakin global.

Hemat peneliti seperti yang Pondok Pesantren Nurul Haramain terapkan yaitu melestariakan lingkungan merupakan konstitusi Negara dan amanah selaku ciptaan manusia, kita sebagai individu pribadi baik sebagai kelompok sosial harus turut mendukung dalam melestarikan lingkungan, karna Rasullah sendri bersabda; "berhatihatilah dengan bumi, sesungguhnya dia adalah Ibumu".

Tentu pendekatan ini berimplikasi pada dua konsep yaitu konsep pemahaman selaku individuaitas dan kolektivitas. Kedua konsep ini adalah sebuah upaya untuk menciptakan setiap perorangan agar lebih meningkatkan kualitas individunya, karena bagaimanapun tanpa kesadaran individu maka dalam memahami situasi kesadaran akan lingkungan akan semakin sulit. Sedangkan konsep kolektivitas adalah daya dukung situasi

${ }^{131}$ Siswanto, Islam Dan Pelestarian Lingkungan Hidup: Menggagas Pendidikan Islam Berwawasan Lingkungan, Karsa, Vol. XIV No. 2, hal 82-90. 2008.

\section{Copyright (C) 2019 Schemata Journal}

Available online at http://journal.uinmataram.ac.id/index.php/schemata 
Zuhaeriah, Manajemen Modernisasi Pendidikan Islam Berwawasan Lingkungan...

yang mnumbuhkan kesadaran bersama dalam memegang amanat sang pencipta maupuk konstitusi sebagaimana yang tertera dalam undang-undang. ${ }^{132}$

Tentu dalam memahami kerangka berfikir yang dmikian adalah bagian dari proses pendidikan based problem solved yang merupakan target bagi sebuah kelembagaan dalam melakukan perubahan sosial dan lingkungan, karena bagaimanapun lingkungan tidak hanya dapat dipetakkan sebagai kesadaran individu namunperlu juga dipahami secara sosial karena hal ini merupakan dasar dalam upaya pengembangan situasi sosial praktis.

Upaya untuk menumbuhkan kesadaran lingkungan melalui pendidikan lingkungan akan memberikan andil besar dalam mencegah perusakan lingkungan lebih jauh bahkan memperbaiki kerusakan yang sudah terjadi. Pendidikan lingkungan hidup merupakan usaha menumbuhkembangkan dan meningkatkan kesadaran komunitas untuk berperilaku ramah terhadap lingkungan sehingga keberlanjutan ekosistem tetap terjaga. Salah satu model pendekatan yang dapat dikembangkan adalah pendidikan ecoPesantren. Eco-Pesantren merupakan model pendidikan yang berusaha untuk menghasilkan santri yang memiliki bekal ilmu yang seimbang antara ilmu duniawi dengan ilmu ukhrowi, sehingga dapat menyeimbangkan antara ibadah mahdhah dengan ibadah ghairu mabdhah serta dapat menerapkan konsep Islam yang utuh, yaitu rahmatan lil'alamin.

Pendidikan berbasis eco-pesanten merupakan kegiatan untuk menjadikan Pondok Pesantren berbasis ramah lingkungan melalui bentuk-bentuk kegiatan seperti peningkatan pola hidup yang ramah lingkungan, pengembangan unit kesehatan dan lingkungan dalam Pesantren, memasukkan kurikulum lingkungan dalam Pesantren serta melakukan aksi nyata dalam pengelolalan sampah, air bersih, sanitasi dan MCK, yang dapat dijadikan percontohan dan pembelajaran bagi masyarakat sekitarnya. Melalui model pendidikan eco-Pesantren ini diharapkan akan melahirkan intelektual Islami yang berorientasi pada mutu, berdaya saing tinggi, dan berbasis pada sikap spiritual tetapi juga ikut andil dalam pembangunan bangsa yang memiliki pola pikir berwawasan lingkungan. ${ }^{133}$

Eco-Pesantren merupakan model pendidikan yang berusaha untuk menghasilkan santri yang memiliki bekal ilmu yang seimbang antara ilmu duniawi (berorientasi pada

${ }^{132}$ Lihat Undang-undang Nomor 32 Tahun 2009 Tentang Perlindungan dan Pengelolaan Lingkungan 133 Jumarddin La Fua Eco-Pesantren; Model Pendidikan Berbasis Pelestarian Lingkungan, Jurnal AlTa'dib Vol. 6 No. 1 Januari-Juni: 38.

\section{Copyright (C) 2019 Schemata Journal}

Available online at http://journal.uinmataram.ac.id/index.php/schemata 
Zuhaeriah, Manajemen Modernisasi Pendidikan Islam Berwawasan Lingkungan...

kehidupan di dunia) dengan ilmu ukhrowi (berorientasi pada kehidupan di akhirat), sehingga dapat menyeimbangkan antara ibadah mabdhah (hubungan dengan Tuhan) dengan ibadah ghairu mahdhah (hubungan dengan makhluk: manusia dan alam) serta dapat menerapkan konsep Islam yang utuh, yaitu rahmatan lil'alamin (kesejahteraan bagi seluruh alam). Pendidikan konservasi melalui model eco-Pesantren merupakan sarana membentuk sumber daya manusia yang memiliki pengetahuan, sikap, keterampilan, dan motivasi serta komitmen untuk ikut memecahkan masalah konservasi dan lingkungan hidup dan mencegah timbulnya permasalahan lingkungan. Pendidikan eco-Pesantren berbasis pelestarian lingkungan merupakan bentuk pendidikan lingkungan hidup di lingkungan Pondok Pesantren yang memfokuskan pada penguatan moral generasi bangsa dalam upaya meningkatkan kesadaran lingkungan yang ditopang oleh tata nilai dan kehidupan spiritual Islam dengan meneruskan risalah Nabi Muhammad SAW sesuai dengan Al-Qur'an dan Hadist yang mengedepankan perlindungan dan pengelolaan lingkungan hidup untuk kemaslahatan umat. Nilai-nilai edukasi yang dikembangkan dalam konsep pendidikan berbasis eco-Pesantren merupakan suatu nilai pendidikan untuk mempersiapkan kader-kader ulama dan intelektual muslim yang memiliki peran penting dan strategis dalam upaya perlindungan dan pengelolaan lingkungan hidup, dengan nilai edukasi seperti ini diharapkan generasi muda memiliki etika, moral dan agama, sehingga dapat menghasilkan generasi muda yang berakhlak mulia dan memiliki nuansa-nuansa lingkungan yang membawa ketentraman dan kesejahteraan secara berkelanjutan tanpa mengurangi hak generasi yang akan datang. ${ }^{134}$

\section{Perspektif Manajemen Green Haramain}

Berdasarkan latar belakang singkat di atas, berikut beberapa faktor yang melatar belakangi secara keseluruhan aspek modernisasi pendidikan Islam berwawasan lingkungan pada Pondok Pesantren Nurul Haramain adalah dengan membangun konsep labelisasi yang bertujuan agar konsep-konsep dalam perspektif lingkungan dapat dipelajari dengan mudah. Eksistensi pohon mempunyai fungsi yang sangat penting dalam upaya meredam kenaikan gas rumah kaca penyebab utama pemanasan global dan perubahan iklim. Seperti spons/busa, pohon menyerap karbon dioksida yang dihasilkan oleh kegiatan-kegiatan yang dilakukan manusia dan makhluk hidup lainnya. Fungsi pohon ini dijalankan dengan sangat masif oleh hutan.

${ }^{134}$ Jumarddin La Fua Eco-Pesantren...., hlm. 41.

Copyright (C) 2019 Schemata Journal

Available online at http://journal.uinmataram.ac.id/index.php/schemata 
Zuhaeriah, Manajemen Modernisasi Pendidikan Islam Berwawasan Lingkungan...

Bila dilihat secara keseluruhan dari beberapa penjelasan yang telah dijelaskan bahwa ada beberapa dampak langsung atau manfaat langsung bagi masyarakat dari hasil dari pohon-pohon yang ditanam mereka;

1. Hutan-hutan gundul dapat dikurangi

2. Mata air yang hilang muncul kembali

3. Kesadaran masyarakat untuk menananm pohon dan mengolah sampah juga meningkat

4. Pemerintah menjadi terbantu tugasnya dan saat ini politicalwill dari pemerintah untuk mengurus lingkungan sudah semakin kuat dan nyata baik dalam membuat aturan2 dan penyiapan pendanaan

5. Nurul Haramain juga mengirim guru-guru pengabdi ke berbagai lembaga di NTB maupun di luar untuk membantu menggalakkan program pelestarian lingkungan di lembaga mereka.

Impact dalam jangka panjang dalam memahami konteks dari system pendidikan Islam adalah menekankan pada asas kebermanfaatn dalam jangka panjang. Investasi yang demikian merupakan salah satu pendekatan yang terkait dengan sebuah manajerisasi tertentu seperti yang telah dijelaskan dalam poin 1-5 di atas.

Nilai-nilai yang digunakan dalam konsep green Haramain adalah memanfaat sumber daya yang potensial dan memanfaatkan peluang-peluang strategis. Artinya bahwa membangun serta mengembangkan potensi yang ada dengan memanfaatkannya secara maksimal massif. Salah satu pendekatannta adalag dengan pendekatan kearifan lokal seperti membuat dan membagikan bibit pohon gratis satu juta bibit setiap tahun. Gerakan yang demikian merupakan model manajemen yang akan berdampak besar dan bersifat berkelanjutan.

Cara yang demikian merupakan bagian daru upaya pembangunan baik secara sosial maupun sumber daya manusia. Sebagaimana yang diterangkan dalam konsep pembangunan sosial yang menyatakan bahwa jika mengukur atau menilai sesuatu dinyatakan baik dan berhasil maka perlu dilihat akan kesadaran individunya, artinya penekanan pada kesadaran individu merupakan catatan penting yang bagian dari konsep pendidikan pada level kognitif. Salah satu contoh lain adalah menanam pohon di lahanlahan kritis milik pemerintah dan milik masyarakat.

Contoh di atas mendeskripsikan bahwa memahami akan eksistensi alam terhadap keberfungsian sosial manusia tentu sangat mempengaruhi baik dalam level individu

\section{Copyright $\odot 2019$ Schemata Journal}

Available online at http://journal.uinmataram.ac.id/index.php/schemata 
Zuhaeriah, Manajemen Modernisasi Pendidikan Islam Berwawasan Lingkungan...

maupun komunitas. Di atas pada bab IV dalam data telah dikemukakan bahwa menanam pohon di pinggiran jalan baypas Gerung BILZAM

Gerakan yang demikian adalah sebuah model dalam perubahan sosial. Perubahan sosial merupakan proses yang berlangsung dalam struktur, fungsi suatu sistem sosial, dan peranan institusi yang berlaku dalam suatu jangka waktu tertentu. Perubahan sosial yang berlangsung mengacu pada kemajuan masyarakat, dengan suatu pola tertentu. Perubahan sosial sebagai perubahan penting dari struktur sosial yang mencakup pola-pola perilaku dan interaksi sosial, yang meliputi norma, nilai, dan fenomena kultural atau dengan perkataan lain perubahan itu merupakan keadaan yang diinginkan, bersifat positif dan bermanfaat, ditimbulkan dan direncanakan. ${ }^{135}$

Dalam kajian teoritis di atas dalam medekonstruksi konsep penghijauan di Pesantren Nurul Haramain maka model manajerisasinya cukup komprehensif dan berimplikasi secara positif. Konsep Green Haramain ini telah berkontribusi secara teoritis maupun praktis dengan menawarkan beberapa model dalam pemberdayaan lingkungan seperti pembentukan MADANI SUPER CAMP yang merupakan sebuah lokasi dalam melakukan perubahan sosial dengan pendekatan system pendidikan Islam modern.

Upaya modernisasi pendidikan dengan pendekatan lingkungan telah dilandasi dengan corak pemikiran-pemikiran yang telah dijelaskan dalam Islam itu sendiri, di dalam hadist Nabi SAW menegaskan tentang perintah menanam pohon (reboisasi), yaitu mengajarkan kepada umatnya untuk menanam tumbuhan baik berupa pohon, biji-bijian, atau tanaman pangan. Nabi SAW juga melarang menebang pohon tanpa mengikuti prosedur yang benar, karena akan mengancam kesinambungan mahluk hidup di bumi.

Dengan adanya penghijauan akan mempercantik wajah dunia dan sekaligus membawa manfaat bagi manusia dan alam, seperti pohon bisa menjadi tempat berteduh, akarnya bisa mencegah terjadinya erosi dan banjir, daunnya bisa menyejukkan pandangan bagi orang yang melihatnya, serta membantu sanitasi lingkungan dalam mengurangi polusi udara dan lain sebaginya.

Demikianlah yang telah diterapkan dalam Pesantren Nurul Haramain Narmada dengan menjadikan lingkungan sebagai asas dakwah dan penyadaran bagi lingkungan santri maupun masyarakat pada umumnya.

${ }^{135}$ Abdul Najib, Integrasi Pekerjaan Sosial, Pengembangan Masyarakat Dan Pemberdayaan Masyarakat (Yogyakarta: Semesta Ilmu, 2016). hal. 27

\section{Copyright (C) 2019 Schemata Journal}

Available online at http://journal.uinmataram.ac.id/index.php/schemata 
Zuhaeriah, Manajemen Modernisasi Pendidikan Islam Berwawasan Lingkungan...

\section{Peningkatan Model Manajemen Pelestarian Lingkungan}

Selain giat menanam pohon, TGH Hasanain juga mencoba mengelola sampah secara mandiri. beliau menjadikan program pengelolaan limbah sebagai materi pendidikan di Pondok Pesantren. Pola pendidikan itu, menurut beliau, dapat melatih para santri menyelesaikan masalah yang mereka ciptakan sendiri. Nurul Haramaian menghasilkan 1,5 ton sampah setiap hari yang berasal dari 2.500 santri dan guru. Prinsip pengelolaannya sangat sederhana. Sampah-sampah itu tidak dibiarkan sampai satu malam.

Tentu dalam menjalankan ide-ide tentang pendidikan lingkungan ini dibutuhkan cara lokal (local wisdom) guna dalam menumbuhkan akan kualitas perindividu seperti cara berfikir berikut. Bila tiap santri sejak memulai mondok menanam dua atau tiga buah pohon maka ketika mereka selesai mondok maka pohon tersebut sudah dapat dipanen dan bias dimanfaatkan utuk masuk perguruan tinggi. Dengan demikian upaya yang model ini sedang dan telah diupayakan sebagai sebuah pedekatan berfikir yang holisstik.

Namun dengan demikian upaya yang telah dilakukan pihak Pondok Pesantren sebagai sebuah proses pembiasaan. Pada hakikatnya membangun dan menjaga lingkungan bagian dari pada perilaku akhlak Islami. Mengingat perilaku dalam menjaga lingkungan yang merupakan bagian dari nilai-nilai inti dalam ajaran Islam. ${ }^{136}$

Pola manajemen yang telah dilakukan dan tetap berjalan hingga dengan manajemen yang berdampak Untuk kelancaran proses pengolahan sampah, berbagai fasilitas dalam membangun tempat pengelolaan sampah dengan instalasi air dan listrik, serta dua mobil khusus pengangkut limbah. Aspek manajerial yang demikian merupakan cara pandang bahwa dalam menyelesaikan masalah di era modern tentu membutuhkan tata cara yang modern pula. Cara yang demikian merupakan bagian dari dari kerangka berfikir dalam memahami masalah, memikirkan masalah serta mengenali berbagai pemungkinan dalam pemecahan, menemukan strategi dalam pemecahan dan melakukan evaluasi.

\section{Menerapkan Semangat Sukarelawan (Filantropis)}

Sukarelawan atau filantropi ${ }^{137}$ merupakan kunci keberhasilan dari sebuah program yang disertai dengan keistiqomahan dari para santri/santriwati dalam

${ }^{136}$ Abudin Nata, Akblak Tasawuf (Jakarta: Raja Grafindo Persada, 2010), hlm. 152.

${ }^{137}$ Filantropi terkait erat dengan upaya-upaya kesejahteraan sosial yang dilakukan para agamawan dan relawan, yakni upaya yang bersifat amal (charity) dimana orang-orang ini menyumbangkan waktu, uang, dan tenaganya untuk menolong orang lain. Pelaku dari filantropi disebut sebagai filantropis. Lihat Abdul Najib,

\section{Copyright (c) 2019 Schemata Journal}

Available online at http://journal.uinmataram.ac.id/index.php/schemata 
Zuhaeriah, Manajemen Modernisasi Pendidikan Islam Berwawasan Lingkungan...

melaksanakan program. Dalam program tersebut dibutuhkan kohevisitas daya dukung alam dan lingkungan agar tejadi keseimbangan dan harmoni, salah satunya adalah penguatan oleh Pondok Pesantren.

Dengan melihat paradigma berfikir manusia modern saat ini tentu menyinggung masalah sukarelawan menjadi tantangan sendiri seiring dengan timbulnya konsep berfikir "tak ada gratis", dengan pola fiikir seperti ini dapat menjadikan ini sebagai sebuah tantangan. Namun Pondok Pesantren Nurul Haramain dengan konsep sukarelawan dengan pendekatan individu serta didukung dengan nilai-nilai social religious (sosial keagamaan) dapat dilaksanakan dengan tertib, sebagaimana yang telah dijelaskan pada bab sebelumnya bahwa Allah menciptakan Alama selain untuk dinikmati juga untuk dijaga.

Pemikiran yang demikian merupakan buah hasil dari penanaman nilai-nilai pendidikan Islam yang diajarkan kepada santri/satriwati melalui pengajaran qur'an dan hadis. Tentu hemat peneliti pada kajian literatur sebaagaimana dalam beberapa data yang telah diverifikasi bahwa sejatinya menciptakan mansia yang berjiwa sosial tingkat tinggi telah ditanamkan dalam beberapa pelajaran-pelajaran hikmah dari cara pandang keagamaan.

Pada dasarnya kepedulian sosial merupakan cirri dari nilai-nilai intrinsic yang terdapat dalam tiap manusia. Kerangka berfikir stake holder Pondok Pesantren Nurul Haramain adalah ingin memupuk santri/santriwati agar memiliki konsep diri (self concept) yang positif. Konsep diripada intinya sikap kepribadian dalam diri seseorang yang mengarahkan pada perkembangan kepribadian perilaku seseorang ditengah masyarakat. ${ }^{138}$

Dengan menekankan pada aspek konsep diri maka model pendidikan yang demikian merupakan bagian dari sebuah upaya berfikir dalam memahami lingkungan termasuk bagaimana memperilakukan lingkungan yang sesuai dengan tuntunan Negara terlebih menurut sang penciptanya. Hemat peneliti secara eksplisit pesantren Nurul Haramain mempolarisasi semangat relawan dalam tiga bentuk diantaranya:

1. Relawan edukasi yaitu sebuah gerakan yang bergerak pada tataran pendidikan, yaitu mengedukasi masyarakat secara umum tentang pentingnya tanggung jawab setiap

Pembangunan Sosial dalam Perspektif Kesejahteraan Sosial dan Pekerjaan Sosial, (Yogyakarta, Samudra Biru, 2018), hlm. 45.

${ }^{138}$ Rahmat. J, Psikologi Komunikasi, (Bandung: Remaja Rosdakarya, 2007). hlm. 99- 100. 
Zuhaeriah, Manajemen Modernisasi Pendidikan Islam Berwawasan Lingkungan...

ummah bagi keberlangsungan ala mini. Biasanya gerkan ini banyak dilakukan melalui acara-acara seminar,lokakarya dan acara sosialisasi lainnya.

2. Relawan konservasi yaitu gerakan dalam mengajak setiap individu untuk melakukan gerakan langsung dalam mensterilkan alam. Contoh yang sering dilakukan adalah mengajak santri dan santriwati membersihkan pantai-pantai dan pasar-pasar agar tetap bersih.

3. Relawan humanis yaitu gerakan yang dilakukan dalam bentuk aksi kemanusiaan. Gerakan yang demikian bertujuan untuk mencipatakan sumber daya yang memiliki ikatan emosional yang baik antar sesame manusia.

Berdasarkan penjelasan di atas tentu lembaga atau institusi keIslaman lainnya tentu ingin memberikan sesuatu yang baik untuk organisasi dan masyarakat.

\section{KESIMPULAN}

Berdasarkan uraian di atas, maka dapat disimpulkan sebagai berikut:

a. Latar belakang pimpinan Pondok dalam menerapkan manajemen modernisasi pendidikan Islam berwawasan lingkungan di Pondok Pesantren Nurul Haramain Narmada Lombok Barat adalah melalui empat aspek diantaranya: (1) Pentingnya Pesantren berbasis IT/Multimedia pada aspek literasi kelingkungan, dalam aspek ini santri/santriwati diajarkan terkait dengan penggunaan IT dengan tujuan untuk mengenal lingkungan dan bagaimana menjaga lingkungan, tentu dalam pemanfaatan ini sangat urgent agar dapat memahami isu-isu lingkungan yang mutakhir saat ini. (2) Manajemen sampah dengan pendekatan Teknologi Tepat Guna, dalam pendekatan ini pengelolaan lingkungan khususnya sampah telah menggunakan pendekatan modern saat ini seperti penyediaan alat pemanas sampah, mesin cuci, alat transportasi pengelolaan sampah dan lain sebagainya. (3) Modernisasi pendidikan dengan aspek sanitasi lingkungan, model pendidikan yang dipraktikkan pada aspek ini adalah membangun akan kesadaran individu dalam kehidupan sehari-hari santri/santriwati seperti memperhatikan lokasi untuk permandian, makanan, minum, tempat tidur, pakaian pribadi, manajemen sampah dan lain sebagainya. (4) Pendekatan Hidden Curriculum Studi Religious Personal pada aspek ini santri/santriwati dididik dengan beberapa kurikulum tersembunyi atau non formal dengan menekankan akan pentingnya nilai-nilai relijius secara individu, hal ini dilakukan agar dapat menciptakan dan menghadirkan pengetahuan, keterampilan baru bagi kebutuhan santri dan santriwati. Dengan dilandasi dengan nilai-nilai Qur'an dan hadis.

\section{Copyright () 2019 Schemata Journal}

Available online at http://journal.uinmataram.ac.id/index.php/schemata 
Zuhaeriah, Manajemen Modernisasi Pendidikan Islam Berwawasan Lingkungan...

b. Upaya-upaya yang dilakukan dalam menerapkan manajemen modernisasi pendidikan Islam berwawasan lingkungan di Pondok Pesantren Nurul Haramain dilakukan melalui tiga aspek/pendekatan yaitu; (1) Pendekatan peduli lingkungan/ program eco-Pesantren, upaya pendekatan seperti yaitu model melestariakan lingkungan yang merupakan amanah bagi ciptaan manusia, manusia sebagai individu dan sebagai kelompok sosial harus turut melestarikan lingkungan, karena Rasullah sendiri bersabda; "berhati-hatilah dengan bumi, sesungguhnya dia adalah Ibumu.” (2) Pendekatan perspektif Green Haramain, yaitu sebuah upaya pembaharuan dan labelisasi Pesantren guna sebagai role model dalam mengembangkan lingkungan (3) peningkatan model manajemen pelestarian lingkungan yaitu meningkatkan gairah dalam menanam pohon, TGH Hasanain yaitu dapat dilakukan mengelola sampah secara mandiri. Dengan demikian diupayakan menjadikan program pengelolaan limbah padat maupun cair sebagai materi pendidikan di Pondok Pesantren. Pola pendidikan itu dapat melatih para santri menyelesaikan masalah yang mereka ciptakan sendiri. (4) Menerapkan semangat sukarelawan (Filantropi), upaya ini merupakan sebuah konsep dengan yang akan dilakukan guna untuk merekrut individuindividu yang memiliki kesadaran individu dengan tingkat tinggi, karena seiringnya dengan kurangnya kontribusi masyarakat dalam menjaga lingkungan.

\section{DAFTAR PUSTAKA}

Arikunto, S. (2002). Prosedur Penelitian Suatu Pendekatan Praktek. Jakarta: Rineka Cipta, Azra, A., (2011). Pendidikan Islam, Tradisi dan Modernisasi Menuju Milenium Baru. Jakarta: Kalimah

Bashori. (2017). Modernisasi Lembaga Pendidikan Pesantren. Dalam Jurnal Ilmu Sosial Mamangan. Vol. 6 (1)

Chirzin, M. H. (2008). “Agama dan Ilmu dalam Pesantren,” Dalam M. Dawam Rahardjo (ed), Pesantren dan Pembaharuan. Jakarta: LP3ES. Cet. VIII

Dahri, H. (2015). Modernisasi Pesantren. Jakarta: Balai Penelitian dan Pengembangan Agama, Heriyudanta, M. (2016) Modernisasi Pendidikan Pesantren Perspektif Azyumardi Azra. Mudarrisa, Jurnal Kajian Pendidikan Islam, Vol. 8(1), 145-172

Husein, Syed S., \& Syed A. A. (2004). Menyongsong Keruntuban Pendidikan Isam,terj. Rahmani Astuti. Bandung: Gema Risalah Press,

Hajar, I. (2009). Kiai di Tengah Pusaran Politik. Yogyakarta: IRCiSoD.

Hasan, M. (2015). Inovasi dan Modernisasi Pendidikan Pondok Pesantren. Jurnal Sosial dan Budaya Keislaman. Vol. 23(2)

Justia, S.. T. (2006). Memahami Aspek-Aspek Pengelolaan Sumber Daya Manusia. Jakarta: Gramedia.

La Fua, J. (2016). Eco-Pesantren; Model Pendidikan Berbasis Pelestarian Lingkungan. Jurnal Al-Ta'dib Vol. 6(1)

\section{Copyright (c) 2019 Schemata Journal}

Available online at $\mathrm{http}: / /$ journal.uinmataram.ac.id/index.php/schemata 
Zuhaeriah, Manajemen Modernisasi Pendidikan Islam Berwawasan Lingkungan...

Madjid, N. (2012) Islam: Doktrin dan Peradaban, Sebuah Telaah Kritis tentang Masalab Keimanan, Kemanusian, dan Kemodernan. Jakarta: Paramadina

Marzuki. (2010). Metodologi Riset. Yogyakarta: BPFE - UII.

Moeleong, L. J. (2002). Metodologi Penelitian Kualitatif. Bandung: Remaja Rosdakarya

Mulkhan, A. M.(2002). Nalar Spiritual Pendidikan: Solusi Problem Filosofis pendidikan Islam. Yogyakarta: Tiara Wacana.

Najib, A. (2016). Integrasi Pekerjaan Sosial,Pengembangan Masyarakat Dan Pemberdayaan Masyarakat. Yogyakarta: Semesta Ilmu.

Najib, A. , (2018). Pembangunan Sosial dalam Perspektif Kesejabteraan Sosial dan Pekerjaan Sosial. Yogyakarta, Samudra Biru

Nasution, H. (2002). Pembaharuan dalam Islam; Sejarah Pemikiran dan Gerakan. Jakarta: Bulan Bintang.

Nata, A. (2010). Akblak Tasawuf. Jakarta: Raja Grafindo Persada.

Ndraha, T.(2002). Research. Jakarta: Bumi Aksara.

Noor, R. M. (2012). The Hidden Curriculum. Yogyakarta: Insan Madani.

Rahardjo, D. (2005). Pesantren dan Pembaharuan. Jakarta: LP3S. Cet. III

Rahman, M. (2011). Humanisasi Pendidikan Islam: Plus Minus Sistem Pendidikan Pesantren. Semarang: Walisongo Press.

Rahman, F.(2004). Islam, Terj. Absin Mubammad. Bandung: Pustaka.

Rahmat. (2007). Psikologi Komunikasi. Bandung: Remaja Rosdakarya.

Setiawan, E. (2007). Modernisasi Pola Sistem Pendidikan Pesantren (Studi Kasus Pondok Pesantren Modern Daarul Fikri Mulyo agung Dau Malang). Pascasarjana Sosiologi Fakultas Pertanian Universitas Brawijaya Malang Telp: 085755597774 email: oke.setia@gmail.com

Siahaan, T. (2004) Hukum Lingkungan dan Ekologi Pembangunan. Jakarta Erlangga.

Siswanto. (2008). Islam Dan Pelestarian Lingkungan Hidup: Menggagas Pendidikan Islam Berwawasan Lingkungan” Karsa, Vol. XIV(2) 82-90.

Soebahar, A. H. (2013). Kebijakan Pendidikan Islam dari Ordonasi Guru sampai UU SISDIKNAS. Jakarta: Rajawali Pers

Solichin, M. M. (2011). Modernisasi Pendidikan Pesantren.” Dalam Jurnal Tadris, Jurusan Tarbiyah STAIN Pamekasan. Volume 6(1): 35-36.

Sugiyono. (2009). Metode Kuantitatif Kualitatif dan R \& D. Bandung:Alfa Beta. CV.

Supriyadi. (2006) Hukum Lingkungan Di Indonesia. Jakarta: Sinar Grafika, 2006.

Tauhied, H. A. (2010). Beberapa Aspek Pendidikan Islam. Yogyakarta: Fak. IAIN Sunan Kalijaga.

Uhbiyati, N. (2009). Ilmu pendidika islam. Bandung: pustaka setia. Cet. 2

Undang-undang Nomor 32 Tahun 2009 Tentang Perlindungan dan Pengelolaan Lingkungan WHO. (2002). Linking Program Evaluation to User Needs, The Politiccs of Program Evolution, Sage, USA.

Yasmadi. (2002). Modernisasi Pesantren, Kritikan Nurcholish Madjid Terbadap Pendidikan Islam Tradisional. Jakarta : Ciputat Press. 
